\title{
Effects of extended voluntary waiting period from calving until first insemination on body condition, milk yield, and lactation persistency
}

\author{
E. E. A. Burgers, ${ }^{1,2 *} \odot$ A. Kok, ${ }^{1,3} \odot$ R. M. A. Goselink, ${ }^{2} \odot$ H. Hogeveen, ${ }^{4} \oplus$ B. Kemp, ${ }^{1} \odot$ \\ and A. T. M. van Knegsel ${ }^{1}$ \\ ${ }^{1}$ Adaptation Physiology Group, Wageningen University \& Research, PO Box 338, $6700 \mathrm{AH}$ Wageningen, the Netherlands \\ ${ }^{2}$ Wageningen Livestock Research, Wageningen University \& Research, PO Box 338, 6700 AH Wageningen, the Netherlands \\ ${ }^{3}$ Animal Production Systems Group, Wageningen University \& Research, PO Box 338, 6700 AH Wageningen, the Netherlands \\ ${ }^{4}$ Business Economics Group, Wageningen University \& Research, PO Box 8130, 6706 KN Wageningen, the Netherlands
}

\section{ABSTRACT}

A 1-yr calving interval (CInt) is usually associated with maximized milk output, due to the calving-related peak in milk yield. Extending CInt could benefit cow health and production efficiency due to fewer transition periods per unit of time. Extending CInt can affect lactation performance by fewer days dry per year, delayed pregnancy effect on milk yield, and greater milk solid yield in late lactation. This study first investigated the effects of 3 different voluntary waiting periods (VWP) from calving until first insemination on body weight, body condition, milk yield, and lactation persistency. Second, individual cow characteristics in early lactation were identified that contributed to milk yield and persistency of cows with different VWP. Holstein-Friesian dairy cows $(\mathrm{n}=154)$ within 1 herd were blocked for parity, calving season, and expected milk yield. Cows were randomly assigned within the blocks to 1 of $3 \mathrm{VWP}$ (50, 125, or 200 d: VWP50, VWP125, or VWP200, respectively) and monitored through 1 complete lactation and the first $6 \mathrm{wk}$ of the subsequent lactation, or until culling. Minimum and mean CInt (384 vs. 452 vs. $501 \mathrm{~d}$ for VWP50 vs. VWP125 vs. VWP200) increased with increasing VWP, but maximum CInt was equal for the 3 VWP. Fat- and protein-corrected milk yield (FPCM) was analyzed weekly. Milk yield and FPCM were also expressed per day of CInt, to compare yields of cows with different VWP. Persistency was determined between d 100 and d 200 of the lactation, as well as between d 100 and dry-off. Values are presented as least squares means \pm standard error of the mean. During the first $44 \mathrm{wk}$ of lactation, VWP did not affect FPCM yield in both primiparous and multiparous cows. The VWP did not affect milk yield per day of CInt. The VWP did not affect FPCM yield per day

\footnotetext{
Received November 14, 2020.

Accepted March 9, 2021.

*Corresponding author: eline.burgers@wur.nl
}

of calving interval for primiparous cows. Multiparous cows in VWP125 had FPCM yield per day of CInt similar to that of VWP50. Multiparous cows in VWP200 had lower FPCM yield per day of CInt compared with VWP50 (27.2 vs. $30.4 \mathrm{~kg} / \mathrm{d}$ ). During the last 6 wk before dry-off, cows in VWP125 had lower yield compared with cows in VWP50, which could benefit their udder health in the dry period and after calving. Persistency was better for cows in VWP200 compared with cows in VWP50 ( -0.05 vs. $-0.07 \mathrm{~kg} / \mathrm{d})$. Body weight was not different among VWP groups. Multiparous cows in VWP200 had a higher body condition score in the last 3 mo before dry-off and the first 6 wk of the next lactation, compared with multiparous cows in VWP125 and VWP50. The VWP could be extended from $50 \mathrm{~d}$ to $125 \mathrm{~d}$ without an effect on daily yield per day of calving interval. Extending VWP until 200 d for primiparous cows did not affect their daily milk yield, but multiparous cows with a 200-d VWP had a reduced milk yield per day of calving interval and an increased body condition in late lactation and the subsequent lactation, compared with multiparous cows with a 50-d VWP.

Key words: extended calving interval, milk production, lactation persistency, individual cow variation

\section{INTRODUCTION}

Traditionally, farmers aim for a 1-yr calving interval (CInt) for their cows, as calving is associated with a peak in milk yield around wk 4 to 7 of lactation (Butler et al., 1981). Around calving, however, cows experience multiple transitions, such as drying off, calving itself, and the start of the next lactation. During these transitions, cows have an increased risk for developing diseases and disorders, such as mastitis, hypocalcemia, and ketosis (Friggens et al., 2004). With a 1-yr CInt, cows face these transitions every year. Moreover, highyielding cows in a 1-yr CInt often have milk yields above $18 \mathrm{~kg}$ at the moment of dry-off, which increases 
the risk for udder infections in the dry period and at calving (Odensten et al., 2007).

To reduce the number of transitions per unit of time, CInt can be extended by extending the voluntary waiting period (VWP) from calving until first insemination. Moreover, extending VWP from 40 to $180 \mathrm{~d}$ resulted in a greater proportion (34.2 vs. $54.6 \%)$ of cows being dried off at lower milk yields $(<15 \mathrm{~kg}$; Niozas et al., 2019), which could be beneficial for udder health (Rajala-Schultz et al., 2005; Odensten et al., 2007) and cow welfare (Zobel et al., 2015). Cows with an extended CInt, however, have fewer peaks in milk yield per unit of time compared with cows with a 1-yr CInt. This could result in a lower milk yield per cow per year. Most studies that analyzed farm data retrospectively found that cows in longer CInt had a lower yearly milk yield compared with cows in shorter CInt (Strandberg and Oltenacu, 1989; Inchaisri et al., 2010; Kok et al., 2019). In such retrospective analyses of farm data, however, extended CInt may be the consequence of health and fertility problems, and cows are not deliberately managed for an extended CInt (Mellado et al., 2016). Moreover, analyses often focused on the 305-d milk yield (Strandberg and Oltenacu, 1989; Steeneveld and Hogeveen, 2012). Cows in an extended CInt, however, have longer lactation periods and fewer days dry per year, which both influence the average milk yield per day and per year (Kok et al., 2019). As an alternative to 305-d milk yield, milk yield could be expressed as the milk yield per day of CInt (Kok et al., 2016; Lehmann et al., 2016), which would account for longer lactation periods or differences in days dry per year.

The CInt has been deliberately extended in experimental studies (Rehn et al., 2000; Arbel et al., 2001; Niozas et al., 2019) and on commercial farms (Lehmann et al., 2016). When CInt was extended from 368 to $430 \mathrm{~d}$ for both primiparous and multiparous cows, milk yield and ECM per day of CInt did not differ (Rehn et al., 2000). Niozas et al. (2019) also reported a similar milk yield and ECM per day of CInt for cows with VWP of 40, 120, and $180 \mathrm{~d}$, and an increase in lactation persistency for the cows with an extended lactation. Milk yield before dry-off was reduced for cows with a VWP of 180 d compared with a VWP of 40 or $120 \mathrm{~d}$ (Niozas et al., 2019). At the time of dry-off, however, cows with a VWP of $180 \mathrm{~d}$ had a higher BCS compared with cows with a VWP of 40 or $120 \mathrm{~d}$, which could negatively affect their health in the subsequent lactation (Roche and Berry, 2006). Fat and protein content were similar (Rehn et al., 2000) or greater (Österman and Bertilsson, 2003) in longer CInt compared with shorter CInt. This could be attributed to an increase in fat and protein content later in lactation (Silvestre et al., 2009). An increase in fat and protein content in longer CInt might compensate for possible lower milk yield.

Parity could affect the results for milk yield of cows after different VWP. When extending CInt for primiparous cows, milk and ECM yield per day of CInt increased, whereas for multiparous cows, yield stayed the same (Arbel et al., 2001; Lehmann et al., 2016) or decreased (Österman and Bertilsson, 2003). Differences among parities concerning consequences of an extended VWP on milk yield could be related to more persistent lactations for primiparous cows compared with multiparous cows (Niozas et al., 2019). Besides parity, other characteristics of individual cows, such as peak yield or persistency, can also be hypothesized to affect milk yield of cows after different VWP. Knowledge on relevant individual cow characteristics related to milk yield after different VWP could support selection of cows for different VWP.

The first aim of this study was to investigate the effect of 3 VWP $(50,125$, and $200 \mathrm{~d})$ on BW, body condition, milk and solids yield, and lactation persistency. The second aim was to see how individual cow characteristics in early lactation, such as parity, maximum yield, time of maximum yield, and slope to maximum yield affect milk yield per day of CInt and persistency in cows with different VWP.

\section{MATERIALS AND METHODS}

\section{Animals and Housing}

The experimental protocol was approved by the Institutional Animal Care and Use Committee of Wageningen University \& Research (Netherlands) and complies with the Dutch law on Animal Experimentation (protocol number 2016.D-0038.005). The experiment was conducted at Dairy Campus research farm (Leeuwarden, Netherlands) between December 2017 and January 2020.

Cows were selected from a research herd of 500 lactating Holstein-Friesian cows based on the following criteria: no twin pregnancy, no clinical mastitis or SCC $>250,000$ at the final 2 milk test days before dry-off, and expected to finish a complete lactation based on being in good general health. The experimental period started at calving and ended 6 wk after the next calving, or at 530 DIM if cows were not pregnant. Cows that were culled were followed until they were culled. Cows were milked twice daily around $0600 \mathrm{~h}$ and $1800 \mathrm{~h}$ in a 40-cow rotary milking parlor (GEA). Partial mixed ration during lactation consisted of grass silage, corn silage, soybean meal, and wheat meal, supporting 22 $\mathrm{kg}$ of milk. Concentrate supply started at $1 \mathrm{~kg} / \mathrm{d}$ on the day of calving, and increased stepwise to $9 \mathrm{~kg} / \mathrm{d}$ 
for primiparous cows or $10 \mathrm{~kg} / \mathrm{d}$ for multiparous cows from d 21 onward. After 100 DIM, individual concentrate supply was decreased to match reductions in milk yield based on the last $5 \mathrm{~d}$ of milk yield. In the milking parlor, $1 \mathrm{~kg}$ of additional concentrate was supplied daily. Ration during the dry period consisted of grass silage and corn silage, supplemented with wheat straw and concentrate. In the last $10 \mathrm{~d}$ before the expected calving date, cows received $1 \mathrm{~kg}$ of concentrate daily. Cows were dried off between 42 and $49 \mathrm{~d}$ before the expected calving date. From 7 d before dry-off, cows were given the dry-cow ration. The $3 \mathrm{~d}$ before dryoff, cows were milked once daily. When cows had SCC $>150,000$ at the final milk test day, cows were treated with antibiotics at dry-off (Orbenin Dry Cow Extra, Zoetis). All cows were treated with teat sealant at dryoff (Orbeseal, Zoetis).

\section{Experimental Design}

In total, 154 cows were selected (41 primiparous, 113 multiparous). In wk 6 after calving, cows were blocked for parity, calving date, 305-d milk yield in the previous lactation (multiparous cows) or expected milk yield (primiparous cows), and breeding value for persistency (CRV). Each block consisted of 3 cows. First, 50 blocks of 3 cows were formed. After removal of 2 cows before the end of VWP due to culling as a result of diseases, 2 more blocks of 3 cows were added. Mean ranges within blocks of the variables used to block the cows are presented in Appendix Table A1. The cows were divided randomly within blocks over 3 treatment groups: a VWP of 50 d (VWP50), 125 d (VWP125), or 200 d (VWP200), resulting in equal absolute difference in days between the 3 groups. Cows in the 3 treatment groups were inseminated after their VWP when estrous was detected. Estrous detection was carried out by using the Nedap Smarttag system as well as visually by the animal caretaker. Cows were inseminated until 300 DIM, meaning that cows in VWP50 had $250 \mathrm{~d}$ to conceive, cows in VWP125 had 175 d to conceive, and cows in VWP200 had $100 \mathrm{~d}$ to conceive. Cows that did not conceive within 300 DIM stayed in the experiment until 530 DIM as long as they produced at least $10 \mathrm{~L}$ of milk per day. Cows left the experiment when milk yield dropped below $10 \mathrm{~L}$ of milk per day based on evaluation of daily milk yield in the preceding $7 \mathrm{~d}$. As a consequence of this approach, 6 cows that did not conceive left the experiment before 530 DIM.

\section{Measurements and Calculations}

Milk yield was recorded at every milking from day of calving until dry-off and the first 6 wk of the next lac- tation. Milk samples for the analysis of fat, protein, and lactose were collected for each individual cow from the container 4 times per week (Tuesday p.m., Wednesday a.m., Wednesday p.m., Thursday a.m.) in 10-mL tubes containing Bronopol as a preservative and analyzed for the percentage of fat, protein, and lactose as a pooled sample (ISO, 2013; Qlip, Zutphen, Netherlands). Body condition score was visually evaluated every $4 \mathrm{wk}$ by the same person using a 1 to 5 scale (Ferguson et al., 1994). Body weight was recorded twice daily after milking, by a scale that the cows walked over when returning from the milking rotary to the pen (GEA).

Milk production was converted to fat- and proteincorrected milk (FPCM) using the following formula (CVB, 2012):

$$
\begin{aligned}
\operatorname{FPCM}(\mathrm{kg})= & \text { milk }(\mathrm{kg}) \times[0.337+0.116 \times \text { fat }(\%) \\
& +0.06 \times \operatorname{protein}(\%)]
\end{aligned}
$$

using the weekly contents of fat, protein, and lactose, and the mean daily milk yield of each week. Milk yield and FPCM yield per day of CInt were calculated for each individual cow for the entire CInt, or from calving until culling. Mean fat, protein, and lactose content was calculated by summing the contents for the entire first lactation within the experiment and dividing them by the number of measurements. Fat, protein, and lactose yields were, similar to milk and FPCM, calculated as kilograms of yield per day of CInt in the first lactation within the experiment. The individual milk or FPCM yield relative to mean milk or FPCM yield in the first 6 wk of lactation of all primiparous or multiparous cows in the experiment (relative yield) was calculated, to include as a covariate in the statistical analysis in some of the models. The first $6 \mathrm{wk}$ are the period before VWP treatment started, so if production differed between groups during this time, their production in the rest of lactation could be corrected with the relative yield in early lactation.

Lactation persistency was defined as the reduction in milk yield after peak yield, and was calculated over 2 different intervals as the slope between (1) d 100 to 200 in lactation and (2) d 100 to start of dry-off ration (7 d before the dry-off date; Chen et al., 2016). Day 100 to 200 was chosen as the period for a standardized persistency for each cow, because no effect of pregnancy on the lactation curve was expected during this period. Day 100 to the start of dry-off was chosen because a difference was expected between short and extended VWP, mainly due to a delayed effect of pregnancy on the lactation curve after extended VWP (Strandberg and Lundberg, 1991). To calculate the slope, first a 2 -sided moving average was made of the milk yield be- 
tween 5 d around d 100 and around d 200 separately (adjusted from Poppe et al., 2020). In this way, to calculate lactation persistency, milk yield at d 100 and d 200 was defined as the mean milk yield of the $2 \mathrm{~d}$ before, the $2 \mathrm{~d}$ after, and the day itself. The moving average of the milk yield at the start of dry-off was calculated over the $5 \mathrm{~d}$ before the start of dry-off. The moving average was used instead of the daily milk yield records to reduce the effcts of daily fluctuations in milk yield on persistency measures.

To evaluate individual cow characteristics that predict cow performance after different VWP, several early-lactation curve characteristics were determined for each cow for the first 6 wk of lactation. First, maximum yield in this period was defined per animal as the greatest 5 -d rolling average milk yield in the first $6 \mathrm{wk}$ of the first lactation within the experiment. Second, day of maximum yield was defined as the day around which the 5-d rolling average yield was greatest, and divided into 3 classes ( $\leq 30 \mathrm{~d}, 31-35 \mathrm{~d}$, and $36-42 \mathrm{~d}$ ). Third, slope to maximum yield was defined as the slope per day from d 10 in lactation until day of maximum yield, and was computed as maximum yield minus the 5 -d rolling average of the milk yield on d 10 in lactation (i.e., the average milk yield from d 8 until d 12), divided by the day of maximum yield minus 10 . Slope to maximum yield was log-transformed to meet the requirement of a normal distribution.

Next to these lactation curve characteristics, the mean FPCM yield, the mean milk yield, fat, protein, and lactose content, fat-to-protein ratio, BCS, and BW were determined per cow for the first 6 wk in lactation.

\section{Statistical Analysis}

Visual inspection of the data indicated normality; non-normally distributed data were transformed. Parity class (primiparous or multiparous cows) refers to the parity of the cow during the first lactation within the experiment.

Model 1: A general linear mixed model (PROC MIXED, SAS version 9.4, SAS Institute Inc.) was used to test the effects of VWP on the dependent variables: CInt (model 1a), dry period length (model 1b), and interval length (i.e., calving interval or interval from calving until the cow left the experiment; model 1c):

$$
\mathrm{y}_{i}=\mu+\mathrm{VWP}_{i}+\varepsilon_{i},
$$

where y represents the dependent variables, $\mu$ represents the mean, $\mathrm{VWP}_{i}$ represents the VWP $(i=50,125$, or $200 \mathrm{~d}$ ), and $\varepsilon_{i}$ represents the random residual term from a normal distribution. Parity class was not included in these models, as preliminary analyses showed it was not significant.

Model 2: A general linear mixed model (PROC MIXED, SAS version 9.4) was used to test the effects of VWP and parity class on the dependent variables: lactation yield per day of CInt [milk (model 2a), FPCM (model 2b), fat (model 2c), protein (model 2d), lactose (model 2e)] and persistency [d 100-200 (model 2e) and d 100 to start of dry-off ration (model 2f)]:

$$
\mathrm{y}_{i j}=\mu+\mathrm{VWP}_{i}+\operatorname{Par}_{j}+(\mathrm{VWP} \times \mathrm{Par})_{i j}+\varepsilon_{i j},[2]
$$

where $\mathrm{y}_{i j}$ represents the dependent variables, $\mu$ represents the mean, $\mathrm{VWP}_{i}$ represents the VWP $(i=50$, 125 , or $200 \mathrm{~d}), \operatorname{Par}_{j}$ represents the parity class $(j=1$ or $2+),(\text { VWP } \times \text { Par })_{i j}$ represents the interaction between VWP and parity class, and $\varepsilon_{i j}$ represents the random residual term from a normal distribution.

Models 3 and 4: These models were adjusted from models $2 \mathrm{a}$ and $2 \mathrm{~b}$ but additionally included relative yield as covariate. These models were performed both including (models $3 \mathrm{a}$ and $3 \mathrm{~b}$ ) and excluding (models $4 \mathrm{a}$ and $4 \mathrm{~b}$ ) cows that did not become pregnant or were culled in the experiment:

$$
\begin{aligned}
& \mathrm{y}_{i j k}=\mu+\mathrm{VWP}_{i}+\mathrm{Par}_{j}+\left(\mathrm{VWP} \times \mathrm{Par}_{i j}\right. \\
& + \text { Relative } \text { Yield }_{k}+\varepsilon_{i j k} \text {, }
\end{aligned}
$$

where Relative Yield $_{k}$ represents the individual milk yield relative to mean yield in the first 6 wk of lactation of all primiparous or multiparous cows in the experiment.

Model 5: A Pearson correlation (PROC CORR, SAS version 9.4) was used to test the relation between persistency between d 100 and 200 and persistency between d 100 and the start of dry-off, for each VWP $\times$ parity class combination and for each VWP class.

Model 6: A repeated measurements model in SAS (PROC MIXED, SAS version 9.4) was used to test the effects of VWP and parity class on the dependent variables milk yield (model 6a), FPCM (model 6b), fat content (model 6c), protein content (model 6d), lactose content (model 6e), and BW (model 6f):

$$
\begin{aligned}
\mathrm{y}_{i j k} & =\mu+\mathrm{VWP}_{i}+\mathrm{Par}_{j}+\mathrm{Week}_{k}+\left(\mathrm{VWP} \times \mathrm{Par}_{i j}\right. \\
& +(\mathrm{VWP} \times \text { Week })_{i k}+(\mathrm{Par} \times \text { Week })_{j k}+\varepsilon_{i j k}, \quad[6]
\end{aligned}
$$

where $\mathrm{y}_{i j k}$ represents the dependent variable, $\mu$ represents the mean, $\mathrm{VWP}_{i}$ represents the VWP $(i=50$, 125 , or $200 \mathrm{~d}), \mathrm{Par}_{j}$ represents the parity class $(j=1$ or $2+)$, Week $k$ represents the lactation week from the first calving within the experiment $(1,2,3, \ldots, 6 ; 1,2,3$, 
$\ldots, 44)$ or lactation week relative to the second calving within the experiment $(-6,-5, \ldots,-1$ or $-12,-11$, $\ldots,-1 ; 1,2,3, \ldots, 6),(\mathrm{VWP} \times \mathrm{Par})_{i j}$ represents the interaction between VWP and parity class, (VWP $\times$ Week $)_{i k}$ represents the interaction between VWP and lactation week, $(\text { Par } \times \text { Week })_{j k}$ represents the interaction between parity class and lactation week, and $\varepsilon_{i j k}$ represents the random residual term from a normal distribution. The model included a repeated measurement effect of lactation weeks with cow as the repeated subject. The same repeated measurements model was used to test the effects of VWP and parity class on the dependent variable BCS (model 6g):

$$
\begin{aligned}
\mathrm{y}_{i j k} & =\mu+\mathrm{VWP}_{i}+\mathrm{Par}_{j}+\text { Month }_{k}+\left(\mathrm{VWP} \times \mathrm{Par}_{i j}\right. \\
& +\left(\mathrm{VWP} \times \mathrm{Month}_{i k}+(\mathrm{Par} \times \text { Month })_{j k}+\varepsilon_{i j k},\right.
\end{aligned}
$$

where Month $_{k}$ represents the lactation month from the first calving within the experiment ( 1 or $2 ; 1,2,3, \ldots$, 11) or lactation month relative to the second calving within the experiment $(-3,-3,-1 ; 1$ or 2$)$.

Models 7 and 8: These models were adjusted from models $6 \mathrm{a}$ and $6 \mathrm{~b}$, additionally including relative yield as covariate. These models were performed both including (models 7a and 7b) and excluding (models 8a and $8 b)$ cows that did not become pregnant or were culled in the experiment:

$$
\begin{aligned}
\mathrm{y}_{i j k l}=\mu & +\mathrm{VWP}_{i}+\mathrm{Par}_{j}+\mathrm{Week}_{k}+\text { Relative } \text { Yield }_{l} \\
& +\left(\mathrm{VWP} \times \mathrm{Par}_{i j}+(\mathrm{VWP} \times \text { Week })_{i k}\right. \\
& +(\mathrm{Par} \times \text { Week })_{j k}+\varepsilon_{i j k l}
\end{aligned}
$$

Models 9 and 10: A general linear model was used to predict individual FPCM yield per day of CInt (model 9) and lactation persistency from d 100 until the start of dry-off (model 10) after different VWP. The following cow characteristics in early lactation (first $6 \mathrm{wk}$ ) were tested: maximum yield, day of maximum yield, slope to maximum yield, mean FPCM yield, mean milk yield, fat, protein, and lactose content, fat-to-protein ratio, BCS, and BW. Next to these early-lactation characteristics, calving date, expected (primiparous cows) or previous (multiparous cows) 305-d milk yield, and breeding value for persistency were tested. First, the effects of each cow characteristic on FPCM yield per day of CInt and on lactation persistency were tested with a univariate analysis, using a general linear mixed model in SAS (PROC MIXED). Second, when $P$-value was $<$ 0.2 , the characteristic was included in the multivariate model. The multivariate model always included VWP and parity class as fixed effects. The cow characteristics in early lactation and their interaction with VWP and parity class stayed in the model if $P<0.05$ by using backward selection.

Model 11: To evaluate the effect of CInt, 3 equal groups with different CInt length were formed of cows that completed the CInt within the experiment: $<415 \mathrm{~d}$ $(\mathrm{n}=43), 415$ to $485 \mathrm{~d}(\mathrm{n}=44)$, or $>485 \mathrm{~d}(\mathrm{n}=40)$. A general linear mixed model (PROC MIXED) was used to test the effects of CInt group and parity class on the dependent variables: lactation yield per day of CInt [milk (model 11a), FPCM (model 11b)] and persistency [d 100 to start of dry-off ration (model 11c)]:

$$
\mathrm{y}_{i j}=\mu+\mathrm{CInt}_{i}+\operatorname{Par}_{j}+\left(\text { CInt } \times \operatorname{Par}_{i j}+\varepsilon_{i j},[11]\right.
$$

where $\mathrm{y}_{i j}$ represents the dependent variables, $\mu$ represents the mean, CInt ${ }_{i}$ represents the CInt group ( $i$ is $<415,415-485$, or $>485$ d), $\operatorname{Par}_{j}$ represents the parity class $(j=1$ or $2+),(\text { CInt } \times \text { Par })_{i j}$ represents the interaction between CInt group and parity class, and $\varepsilon_{i j}$ represents the random residual term from a normal distribution. Results of this model are presented in Appendix Table A2.

Values are presented as least squares means \pm standard error of the mean. All $P$-values of pair-wise comparisons of least squares means were corrected with a Bonferroni adjustment.

\section{RESULTS}

From the 154 cows that entered the experiment, 127 cows started a second lactation within the experiment. These cows were followed for a complete lactation and 6 wk into the next lactation. In total, 14 cows did not become pregnant during the first lactation (2 from VWP50, 3 from VWP125, 9 from VWP200), and 13 cows were culled due to health issues (5 from VWP50, 4 from VWP125, 4 from VWP200). Cows that were culled before the end of the experiment were followed until they were culled. Excluding culled and nonpregnant cows, calving interval was $384( \pm 6.75), 452( \pm 7.14)$, or 501 $( \pm 7.50)$ d for cows in VWP50, VWP125, or VWP200 (Table 1). Dry period length did not differ among the 3 VWP groups. Including culled and nonpregnant cows, interval length was $363( \pm 12.2), 445( \pm 12.8)$, or 481 $( \pm 12.5) \mathrm{d}$ for cows in VWP50, VWP125, or VWP200 (Table 2).

\section{Lactation Yield per Day of Calving Interval}

The VWP did not affect the milk yield per day of CInt for primiparous or multiparous cows (Table 3). The VWP did not affect FPCM yield per day of CInt for primiparous cows, whereas FPCM yield per day of 
Table 1. Calving interval (CInt, d) and dry period length (DP, d) of the 127 cows that had a second calf within the experiment and had a voluntary waiting period after calving until first insemination of 50, 125, or 200 d (VWP50, VWP125, or VWP200) $)^{1}$

\begin{tabular}{lcccrrc}
\hline Waiting period & CInt & Range & SEM & DP & Range & SEM \\
\hline VWP50 & $384^{\mathrm{a}}$ & $324-565$ & 6.75 & 41 & $18-63$ & 1.4 \\
VWP125 & $452^{\mathrm{b}}$ & $400-586$ & 7.14 & 42 & $8-72$ & 1.5 \\
VWP200 & $501^{\mathrm{c}}$ & $469-575$ & 7.50 & 43 & $8-75$ & 1.6 \\
\hline
\end{tabular}

${ }^{\mathrm{a}-\mathrm{c}}$ Different superscript letters indicate a difference among LSM within the column. a-b: $P<0.01$; a-c: $P<$ $0.01 ; \mathrm{b}-\mathrm{c}: P<0.01$.

${ }^{1}$ Values represent LSM, range, and SEM.

CInt was higher for multiparous cows in VWP50 compared with multiparous cows in VWP200. When the relative yield in the first $6 \mathrm{wk}$ was included in the model as a covariate, FPCM yield per day of CInt tended to be higher for multiparous cows in VWP50 compared with multiparous cows in VWP200. When only cows that had a second calf were included, FPCM yield per day of CInt was higher for multiparous cows in VWP50 compared with multiparous cows in VWP200, both with and without correction for the relative yield.

The VWP did not affect the protein or lactose yield per day of CInt. The fat yield per day of CInt was greater for multiparous cows compared with primiparous cows (1.18 vs. $1.03 \mathrm{~kg} / \mathrm{d}, P<0.01)$. The protein yield per day of CInt was greater for multiparous cows compared with primiparous cows $(1.00$ vs. $0.86 \mathrm{~kg} / \mathrm{d}, P$ $<0.01)$. The lactose yield per day of CInt was greater for multiparous cows compared with primiparous cows (1.24 vs. $1.07 \mathrm{~kg} / \mathrm{d}, P<0.01)$.

\section{Lactation Persistency}

The VWP did not affect the persistency between $\mathrm{d}$ 100 and 200 of the lactation. Between d 100 and the start of dry-off, cows in VWP200 were more persistent compared with cows in VWP50 ( -0.05 vs. $-0.07 \mathrm{~kg} / \mathrm{d}$, $P=0.02)$. Primiparous cows were more persistent compared with multiparous cows between d 100 and 200 ( -0.04 vs. $-0.09 \mathrm{~kg} / \mathrm{d}, P<0.01)$ and between $\mathrm{d}$

Table 2. Interval length (d) of all 154 cows within the experiment that had a voluntary waiting period after calving until first insemination of 50,125 , or 200 d (VWP50, VWP125, or VWP200) ${ }^{1}$

\begin{tabular}{lcrc}
\hline Waiting period & Interval length $^{2}$ & Range & SEM \\
\hline VWP50 & $363^{\mathrm{a}}$ & $43-565$ & 12.2 \\
VWP125 & $445^{\mathrm{b}}$ & $203-586$ & 12.8 \\
VWP200 & $481^{\mathrm{b}}$ & $69-575$ & 12.5 \\
\hline
\end{tabular}

\footnotetext{
${ }^{\mathrm{a}, \mathrm{b}}$ Different superscript letters indicate a difference among LSM within the column. a-b: $P<0.01$; b-b: $P=0.14$.

${ }^{1}$ Values represent LSM, range, and SEM.

${ }^{2}$ Calving interval or interval from calving until the cow left the experiment.
}

100 and the start of dry-off $(-0.04$ vs. $-0.08 \mathrm{~kg} / \mathrm{d}, P$ $<0.01)$.

For multiparous cows in VWP125 and VWP200, we detected a correlation between persistency between $\mathrm{d}$ 100 and 200 and persistency between d 100 and the start of dry-off (VWP125: 0.56, $P<0.01$; VWP200: 0.74, $P$ $<0.01)$. For primiparous cows in VWP50, we detected a trend for correlation between the 2 persistency measures $(0.51, P=0.07)$. For the other VWP $\times$ parity class combinations no correlation between the persistency measures was detectable. Overall, in VWP200 correlation between the 2 persistency measures was strongest $(0.74, P<0.01)$, followed by VWP125 (0.69, $P<0.01)$, and VWP50 $(0.44, P<0.01)$.

\section{Milk Yield Before Dry-Off}

During the last 6 wk before dry-off, after different VWP, VWP affected milk and FPCM yield, where cows in VWP50 had greater yield compared with VWP125 (milk: $18.9 \pm 0.74$ vs. $16.0 \pm 0.75 \mathrm{~kg} / \mathrm{d}, P$ $=0.02$; FPCM: $22.1 \pm 0.83$ vs. $19.3 \pm 0.84 \mathrm{~kg} / \mathrm{d}, P=$ $0.047)$ and tended to have greater yield compared with VWP200 (milk: $18.9 \pm 0.74$ vs. $16.1 \pm 0.90 \mathrm{~kg} / \mathrm{d}, P$ $=0.05 ;$ FPCM: $22.1 \pm 0.83$ vs. $19.2 \pm 1.01 \mathrm{~kg} / \mathrm{d}, P=$ $0.08)$. At the moment of dry-off, milk yield was greater for cows in VWP50 compared with cows in VWP125 $(18.2 \pm 0.89$ vs. $14.5 \pm 0.91 \mathrm{~kg} / \mathrm{d}, P=0.01)$, and both VWP50 and VWP125 did not differ from VWP200 $(15.4 \pm 1.10 \mathrm{~kg} / \mathrm{d})$.

\section{Weekly Milk Yield and Fat, Protein, and Lactose Content}

During the first 44 wk of lactation, effect of VWP on milk yield and FPCM depended on week in lactation, and effect on milk yield tended to depend on parity (Table 4). Milk yield tended to be higher for multiparous cows in VWP125 compared with multiparous cows in VWP200. When the relative yield in the first $6 \mathrm{wk}$ was included in the model, no differences in milk or FPCM yield were detectable among the $\mathrm{VWP} \times$ parity 


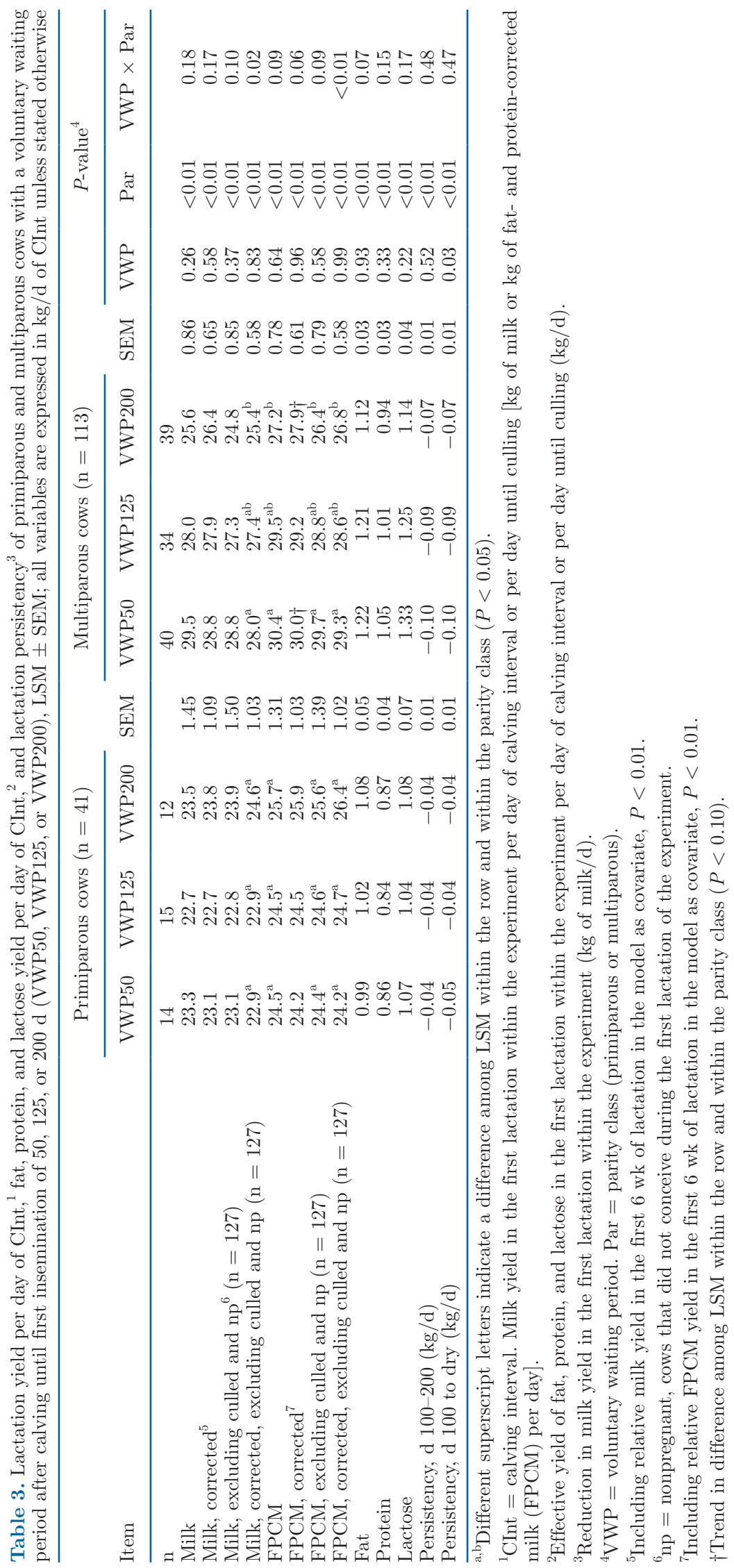


classes, but FPCM yield tended to be higher for cows in VWP125 compared with cows in VWP50 (31.1 vs. 29.9 $\mathrm{kg} / \mathrm{d}, P=0.08)$. When only cows that had a second calf were included and relative yield was included as a covariate, primiparous cows in VWP200 had greater milk and FPCM yield compared with primiparous cows in VWP50. In this model, cows in VWP200 tended to have greater yield compared with cows in VWP50 (milk: 30.5 vs. $29.1 \mathrm{~kg} / \mathrm{d}, P=0.08$; FPCM: 31.5 vs. $30.3 \mathrm{~kg} / \mathrm{d}, P=0.08)$.

The VWP did not affect fat, protein, or lactose content in the first $44 \mathrm{wk}$ of lactation. Parity class did not affect fat or protein content. The lactose content was greater for primiparous cows compared with multiparous cows (4.60 vs. $4.47 \%, P<0.01)$.

During the first 6 wk of the second lactation within the experiment, cows in VWP50 tended to have greater milk yield compared with cows in VWP200 (37.4 vs. $33.7 \mathrm{~kg} / \mathrm{d}, P=0.05)$. No differences were detectable among the VWP groups in FPCM in the first 6 wk of the second lactation.

\section{Weekly BW and Monthly BCS}

Voluntary waiting period did not affect BW or BCS during the first $44 \mathrm{wk}$ of the lactation. During the last 12 wk before dry-off, multiparous cows in VWP200 had higher BCS compared with multiparous cows in VWP50 and VWP125 (Table 5). The VWP did not affect BW or BCS in late lactation of primiparous cows or in their subsequent lactation. For multiparous cows, during the first $6 \mathrm{wk}$ of the second lactation within the experiment, VWP200 resulted in a higher BCS compared with VWP50 and VWP125.

During the first $44 \mathrm{wk}$ of lactation, primiparous cows had lower BW compared with multiparous cows (588 vs. $693, P<0.01)$ and higher BCS compared with multiparous cows (2.5 vs. 2.3, $P<0.01$ ). During the last 12 wk before dry-off, primiparous cows had lower BW compared with multiparous cows $(663$ vs. $756 \mathrm{~kg}, P<$ $0.01)$.

\section{Cow Characteristics as Predictors for Lactation Performance}

After backward selection, the final multivariate model for FPCM yield per day of CInt included VWP class and parity class as class variables, and FPCM, milk yield, BW, interaction of $\mathrm{BW} \times$ parity class, maximum yield, interaction maximum yield $\times$ VWP, slope to maximum yield, interaction of slope to maximum yield $\times$ VWP, expected (primiparous cows) or previous (multiparous cows) 305-d milk yield, breeding value for persistency, and interaction of breeding value for per- sistency $\times$ VWP as continuous variables (Table 6 ). In this model, maximum yield in the first 6 wk of lactation was positively associated with FPCM per day of CInt in all VWP groups, most in VWP50. Slope to maximum yield was positively associated with FPCM per day of CInt in VWP125 and negatively associated with FPCM per day of CInt in VWP50 and VWP200. The breeding value for persistency was positively associated with FPCM per day of CInt in all VWP groups, most in VWP200. Mean BW in the first 6 wk of lactation was positively associated with FPCM per day of CInt for primiparous cows and negatively associated with FPCM per day of CInt for multiparous cows. Mean FPCM in the first $6 \mathrm{wk}$ of lactation was positively associated with FPCM per day of CInt, whereas mean milk yield in the first 6 wk of lactation was negatively associated with FPCM per day of CInt.

After backward selection, the final multivariate model for lactation persistency from d 100 until the start of dry-off included VWP class and parity class as class variables, and milk yield, interaction of milk yield $\times$ VWP, maximum yield, interaction of maximum yield $\times$ VWP, and expected (primiparous cows) or previous (multiparous cows) 305-d yield as continuous variables (Table 7). In this model, mean milk yield in the first 6 wk of lactation was negatively associated with lactation persistency in VWP125 and VWP200, and positively associated with lactation persistency in VWP50. Maximum milk yield in the first 6 wk of lactation was negatively associated with lactation persistency in VWP50 and positively associated with lactation persistency in VWP125 and VWP200. Expected or previous 305-d yield was negatively associated with lactation persistency.

\section{DISCUSSION}

Increasing VWP until $200 \mathrm{~d}$ did not affect milk or FPCM yield per day of CInt for primiparous cows. Primiparous cows seem to be appropriate to select for an extended VWP, without losing milk. This is comparable to other studies, where primiparous cows kept for extended lactations achieved similar or even greater lactation yields compared with primiparous cows in shorter lactations (Arbel et al., 2001; Lehmann et al., 2016). The main reason that primiparous cows achieve the same yield per day of CInt after an extended VWP as after a short VWP of $50 \mathrm{~d}$ is their high lactation persistency (Arbel et al., 2001; Lehmann et al., 2016; Niozas et al., 2019). Also in the current study, primiparous cows had greater lactation persistency compared with multiparous cows. This higher persistency of primiparous cows compared with multiparous cows possibly also resulted in their higher yield in the last $6 \mathrm{wk}$ 
Burgers et al.: MILK YIELD AND PERSISTENCY IN EXTENDED LACTATIONS

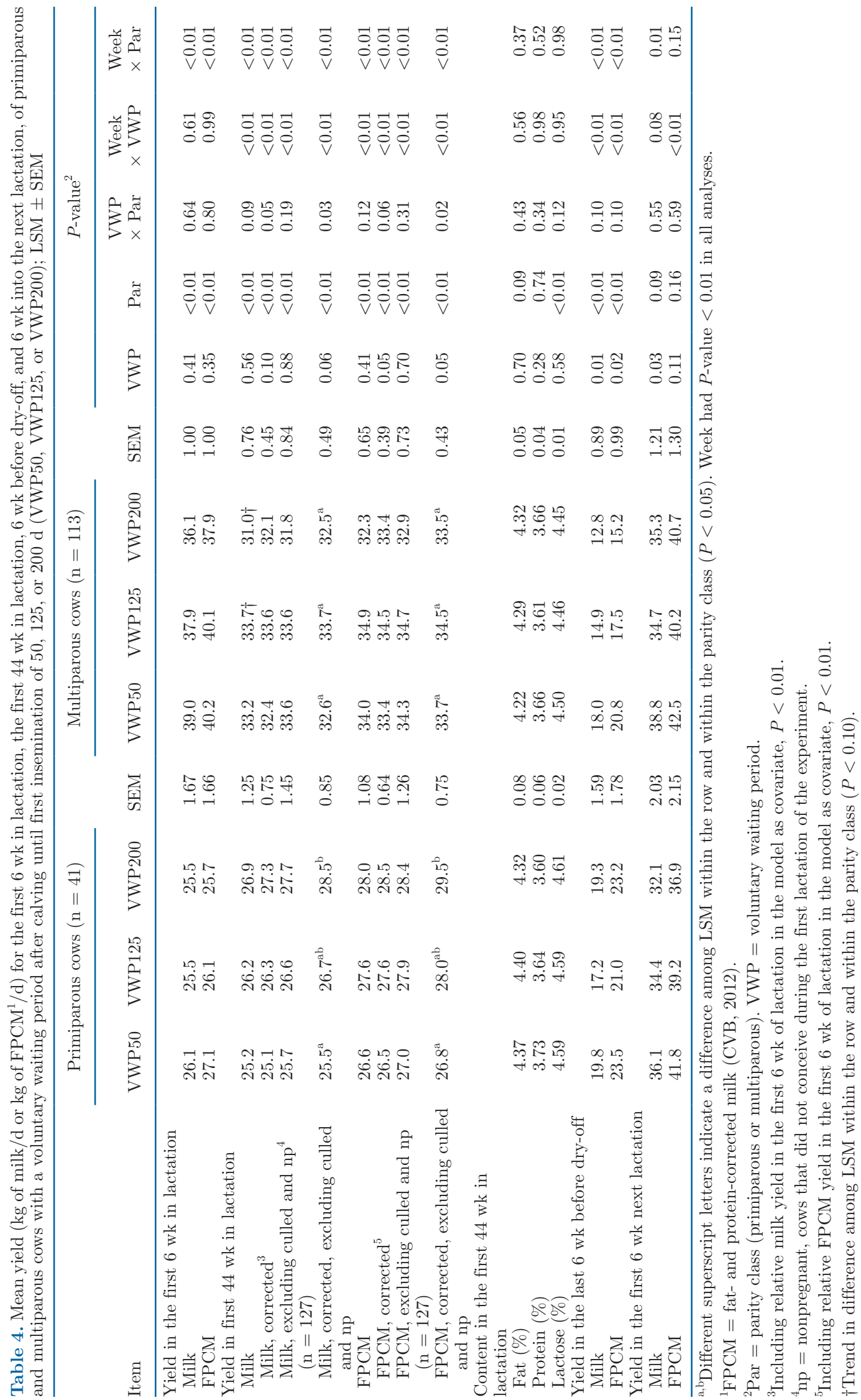




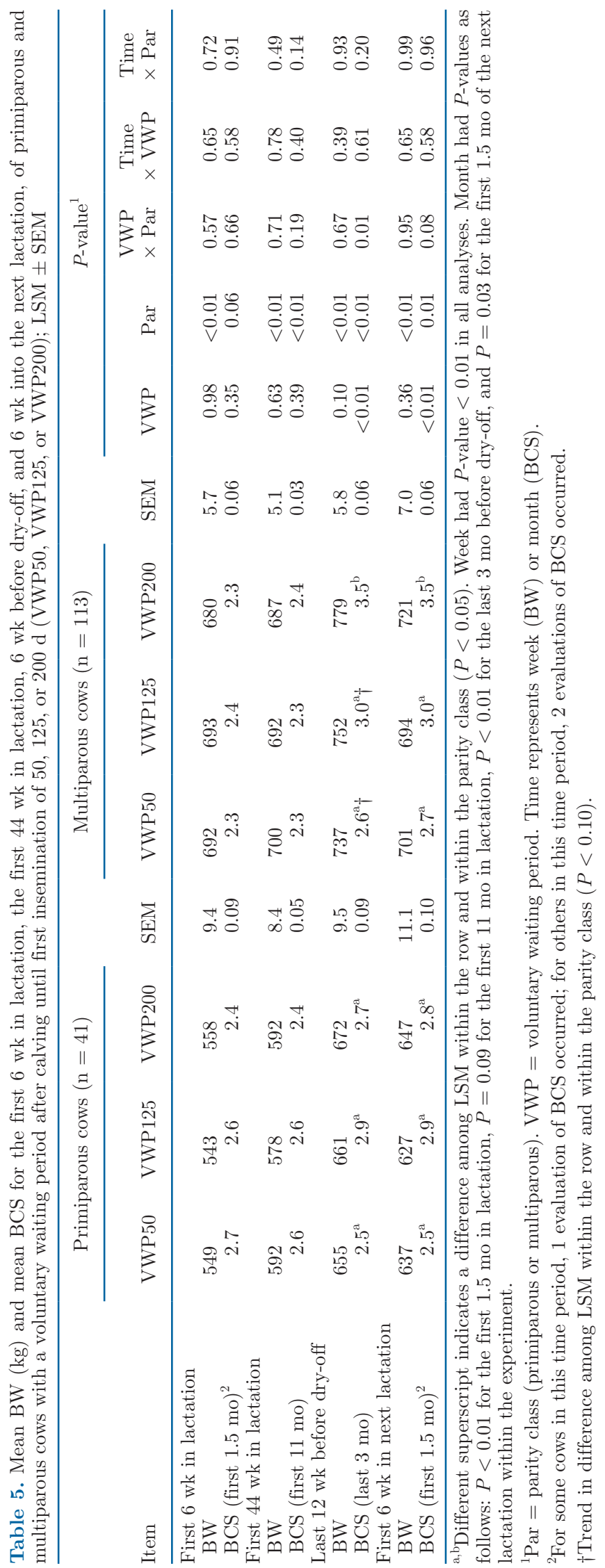

before and at dry-off in the current study. When primiparous cows are kept for an extended CInt, however, they take more time to become a second-parity cow. Second-parity cows are, in general, more productive than primiparous cows (Friggens et al., 1999; Lee and Kim, 2006). Therefore, when primiparous cows were kept for an extended CInt, this still resulted in a loss in milk yield at herd level (Kok et al., 2019).

Increasing VWP until 125 d did not affect milk or FPCM yield per day of CInt for multiparous cows. When extending VWP further, until $200 \mathrm{~d}$, the yield per day of CInt was lower compared with VWP50. This difference was around 2 to $4 \mathrm{~kg} / \mathrm{d}$, depending on whether culled and nonpregnant cows were included or whether a correction for the relative yield was used. The reason for the lower production of multiparous cows in VWP200 could be that they have more days at the end of this long lactation, where milk yield is usually lower. Also, in our earlier study at commercial farms, cows with the greatest production potential that had calving intervals $>531 \mathrm{~d}$ could not sustain production in these long CInt (Burgers et al., 2021). In that study, however, the long CInt consisted of both cows with a voluntarily extended waiting period for insemination and cows that failed to conceive at earlier insemination(s). In another study, milk yield per day of CInt did not decrease when calving interval was extended up to 18 mo (Österman and Bertilsson, 2003). In that study, some of the cows were milked 3 times per day, increasing their peak milk yield and their persistency, resulting in similar productions compared with a calving interval of 12 mo. In line with other studies on deliberately extended lactations (Arbel et al., 2001; Lehmann et al., 2016), we used yield per day of CInt to compare milk yield after different VWP. Moreover, yield per day of CInt is economically of interest: extended lactations can be profitable when yield per day of CInt is maintained at similar levels as in shorter CInt, or when milk yield losses can be compensated for by lower costs, as for insemination, feed, or disease.

At the moment of dry-off, milk yield was lower for cows in VWP125 compared with cows in VWP50. Yield for cows in VWP200 was not significantly lower at dryoff compared with cows in VWP125 or VWP50. This could be explained by the greater lactation persistency between d 100 and the start of dry-off of cows with a VWP of $200 \mathrm{~d}$ compared with cows after a VWP of 50 $\mathrm{d}$, possibly related to a delayed effect of pregnancy on the lactation curve due to later gestation (Strandberg and Lundberg, 1991; Kok et al., 2019). Although milk yield decreased in late lactation, fat and protein content in milk increased toward late lactation, as it did in an earlier study (Silvestre et al., 2009). The total solid yield, however, did not increase in our study, as 
Table 6. Final multivariable model for prediction of fat- and protein-corrected milk yield (FPCM) per day of calving interval (in $\mathrm{kg} / \mathrm{d}$ ) for cows with a voluntary waiting period (VWP) after calving until first insemination of 50, 125, or $200 \mathrm{~d}$ (VWP50, VWP125, or VWP200); LSM \pm SEM or regression coefficient $(\beta)$ with $\mathrm{SE}$ and range ${ }^{1}$

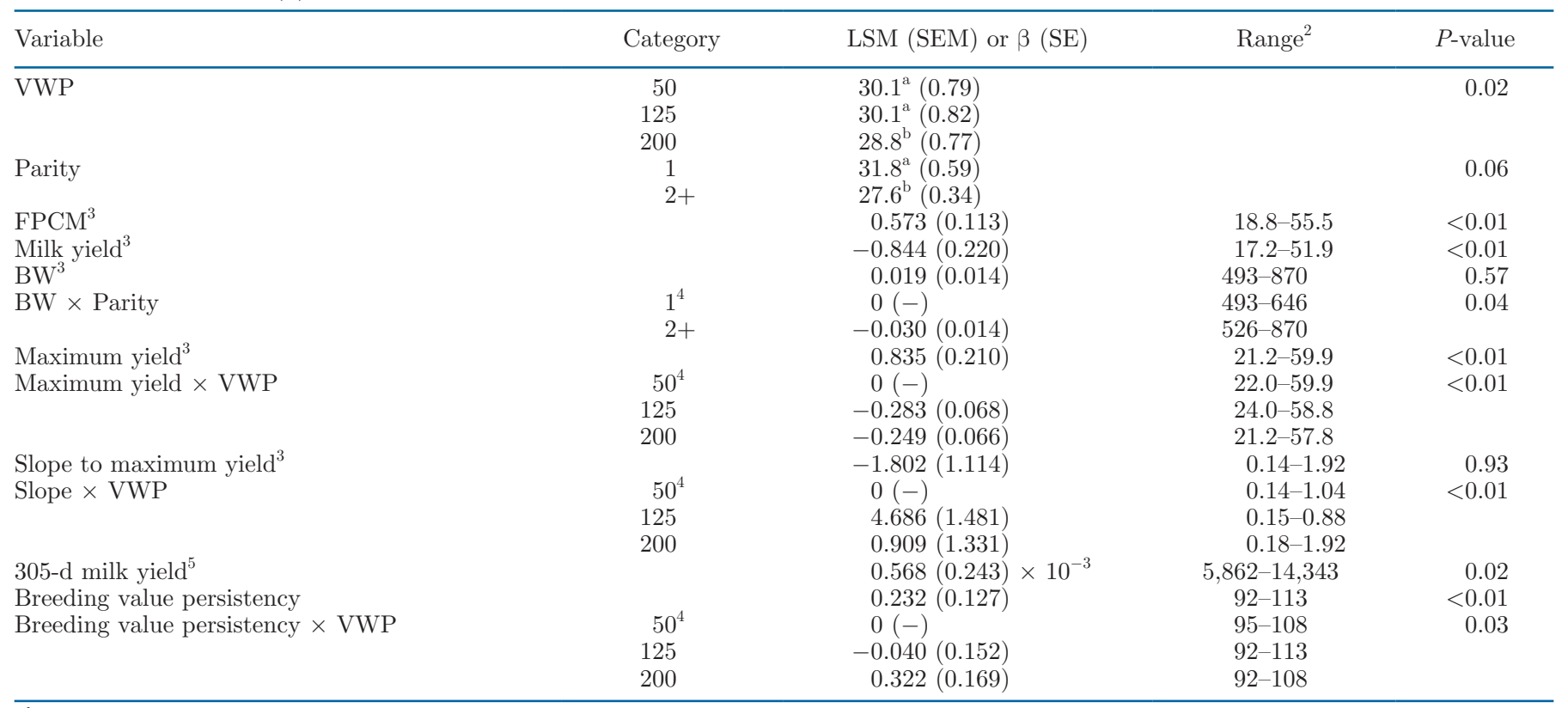

${ }_{\mathrm{a}, \mathrm{b}}$ Different superscript letters indicate a difference among LSM within the column within 1 variable $(P<0.05)$.

${ }^{1}$ The final multivariate model was based on 14 univariate models, with individual early-lactation variables as independent variable, to identify potential predictors for milk yield after different VWP.

${ }^{2}$ Ranges for FPCM, milk yield, maximum yield, and slope to maximum yield in $\mathrm{kg} / \mathrm{d}$; ranges for BW and 305-d milk yield in $\mathrm{kg}$.

${ }^{3}$ Measured in the first 6 wk after the first calving within the experiment.

${ }^{4}$ Reference category.

${ }^{5}$ Expected (primiparous cows) or previous (multiparous cows) 305-d milk yield.

Table 7. Final multivariable model for prediction of lactation persistency (in $\mathrm{kg} / \mathrm{d}$ ) between $\mathrm{d} 100$ and start of dry-off for cows with a voluntary waiting period (VWP) after calving until first insemination of 50, 125, or $200 \mathrm{~d}$ (VWP50, VWP125, or VWP200); LSM \pm SEM or regression coefficient $(\beta)$ with SE and range ${ }^{1}$

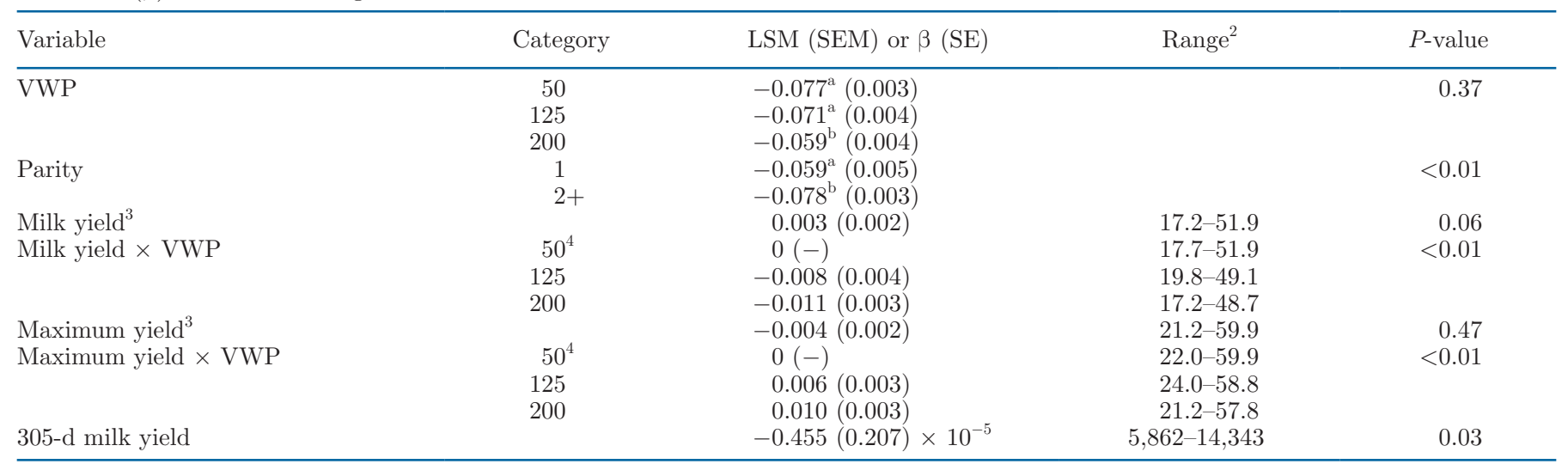

${ }^{\mathrm{a}, \mathrm{b}}$ Different superscript letters indicate a difference among LSM within the column within 1 variable $(P<0.05)$.

${ }^{1}$ The final multivariate model was based on 14 univariate models, with individual early-lactation variables as independent variable, to identify potential predictors for lactation persistency after different VWP.

${ }^{2}$ Ranges for milk yield and maximum yield in $\mathrm{kg} / \mathrm{d}$; range for $305-\mathrm{d}$ milk yield in $\mathrm{kg}$.

${ }^{3}$ Measured in the first $6 \mathrm{wk}$ after the first calving within the experiment.

${ }^{4}$ Reference category. 
the total production of milk was lower in late lactation, especially after extended VWP. In the current study, an extended VWP relative to a VWP of $50 \mathrm{~d}$ resulted in a lower milk yield before dry-off, which could benefit udder health in the dry period and at calving (RajalaSchultz et al., 2005; Odensten et al., 2007). The lower milk yield before dry-off could be related to an increased risk for fattening of cows in late lactation. The BCS of cows in VWP200 and VWP125 were 3.1 and 2.9 during the last 3 mo before dry-off, compared with a BCS of 2.6 for cows in VWP50. This greater BCS could increase the risk for diseases after next calving (Roche and Berry, 2006).

During the first $44 \mathrm{wk}$ in lactation, we detected no differences for FPCM yield among VWP groups. During the first $6 \mathrm{wk}$ of the lactation where VWP treatment was applied, both FPCM and milk yield were numerically lower for multiparous cows with VWP200 compared with multiparous cows with VWP50, and VWP125 had a yield in between. During the first 6 wk, no effect of VWP is possible, and therefore we corrected the 305-d milk yield for the yield in these first 6 wk. After this correction, and only including cows that had a second calf within the experiment, primiparous cows in VWP200 had greater 305-d yield compared with primiparous cows in VWP50. During the last 50 $\mathrm{d}$ of the first $305 \mathrm{~d}$, pregnancy could already affect the lactation curves of some cows in VWP50 (Strandberg and Lundberg, 1991; Kok et al., 2019). This pregnancy effect may explain the somewhat lower 305-d yield in VWP50.

During the first 6 wk of the second lactation within the experiment, cows in VWP50 tended to have greater milk yield compared with cows in longer VWP, but FPCM yield was the same in the 3 VWP groups. Although primiparous cows from VWP200 did have more time to grow before their second calving compared with primiparous cows from VWP50, they did not achieve greater milk yield or FPCM during the first 6 wk after the second calving. In an earlier study, the increase in milk production in the subsequent lactation compared with the previous lactation was greater for primiparous and multiparous cows that had 2 subsequent lactations of 18 mo compared with 2 subsequent lactations of 12 mo (Österman and Bertilsson, 2003). In observational data from commercial farms, second-parity cows achieved greater ECM per day of CInt when their previous CInt was extended compared with when their previous CInt was shorter (Lehmann et al., 2016). In the current experiment, we monitored only the first 42 $\mathrm{d}$ of the next lactation. This may be too short a time period for cows to show their possible higher production potential. Another reason for the tendency for lower milk yield in VWP200 could be that only 9 out of 12 primiparous cows in VWP200 had a second calf, which is a relatively low number, also compared with the primiparous cows in VWP125 (14 out of 15) and in VWP50 (13 out of 14).

Fat- and protein-corrected milk yield per day of CInt of cows with different VWP could be predicted by the maximum yield in the first 6 wk of lactation, the slope to this maximum yield, and the breeding value for persistency. In the model, the breeding value for persistency had a more positive relation with FPCM per day of CInt in VWP200, with VWP50 as a reference value. This could indicate that cows with a greater breeding value for persistency perform better in VWP200 compared with VWP50 in terms of FPCM yield per day of CInt, possibly related to the higher importance of lactation persistency for total milk yield after longer VWP for insemination compared with a shorter VWP (Lehmann et al., 2016; Kok et al., 2019). Moreover, in the model, maximum yield had a less positive effect on FPCM per day of CInt in the longer VWP groups compared with VWP50, possibly related to the lower lactation persistency that is related to a greater peak yield (Dekkers et al., 1998).

Lactation persistency between d 100 and moment of dry-off of cows with different VWP could be predicted by mean milk yield and maximum yield in the first 6 wk. In VWP50, mean milk yield had a positive relation to lactation persistency, and maximum yield had a negative relation to lactation persistency. In VWP125 and VWP200, these effects were reversed compared with VWP50. A higher peak yield is often associated with lower persistency (Dekkers et al., 1998). This can be related to the more negative energy balance when peak yield is higher, which could be related to reduced persistency in later lactation (Chen et al., 2016). Next to these early-lactation production characteristics, the expected (primiparous cows) or previous (multiparous cows) 305-d yield was also related to lactation persistency between d 100 and the start of dry-off. A greater 305-d yield was related to lower persistency, possibly because a greater 305-d yield is often related to a greater peak yield, which is related to decreased persistency (Dekkers et al., 1998; Chen et al., 2016).

In the current study, we investigated the effects of 3 VWP on milk yield and lactation persistency in a controlled experiment, in contrast with the work on extended lactations that is performed in observational studies on farms (e.g., Lehmann et al., 2016; Mellado et al., 2016; Burgers et al., 2021). All cows were blocked and randomly assigned to one of the 3 VWP groups, which had a fixed VWP in days, making it possible to find cow characteristics that contribute to milk yield of individual cows in different lactation lengths. Some of the cow characteristics found in this study that affected 
total lactation yield or persistency after different VWP might be additionally used by farmers to optimize VWP for individual cows. Selecting specific cows for extended VWP could imply that herd-level benefits of longer CInt, such as reduced frequency of transitions such as dry-off and calving, reduced labor related to these transitions and reduced the number of surplus calves, as well as minimizing loss of milk yield on a herd level. Some farmers already used different cow characteristics in early lactation to determine for which cows they extended the VWP (Lehmann et al., 2016; Burgers et al., 2021). Early-lactation characteristics that were used in our earlier study included maximum yield, BCS, and BW (Burgers et al., 2021). In practice, farmers often extended VWP until cows reached a certain milk level (Burgers et al., 2021). Waiting until milk drops below a certain level helps in selecting more persistent cows for longer CInt, as the longer a cow takes to reach this milk level, the longer the VWP will be, and often the more persistent this cow is. Together with the earlylactation cow characteristics, a waiting period based on milk level might contribute to an individual approach for extended VWP management.

\section{CONCLUSIONS}

For both primiparous and multiparous cows, VWP was extended until $125 \mathrm{~d}$ with no effect on milk or FPCM yield per day of CInt. For primiparous cows, extending the VWP further until $200 \mathrm{~d}$ still did not affect yield per day of CInt, although, for multiparous cows, extending the VWP to $200 \mathrm{~d}$ resulted in a lower yield per day of CInt. Moreover, cows in longer VWP had lower yield at dry-off, which may benefit their udder health during the dry period and possibly also the subsequent lactation. On the contrary, multiparous cows in longer VWP had higher BCS at dry-off and in the first weeks of the subsequent lactation, which may hamper metabolic health and adaptation to a new lactation. Milk characteristics in the first 6 wk of lactation and the breeding value for persistency determined cow performance after different VWP.

\section{ACKNOWLEDGMENTS}

The authors thank the staff of the Dairy Campus (Leeuwarden, Netherlands). This study was financed by DairyNL (ZuivelNL; organization of the Dutch dairy supply chain) and the Dutch Ministry of Agriculture, Nature and Food Quality (LNV) as part of the research program One Health for Food $(1 \mathrm{H} 4 \mathrm{~F})$. The authors have not stated any conflicts of interest.

\section{REFERENCES}

Arbel, R., Y. Bigun, E. Ezra, H. Sturman, and D. Hojman. 2001. The effect of extended calving intervals in high lactating cows on milk production and profitability. J. Dairy Sci. 84:600-608. https://doi .org/10.3168/jds.S0022-0302(01)74513-4.

Burgers, E. E. A., A. Kok, R. M. A. Goselink, H. Hogeveen, B. Kemp, and A. T. M. Van Knegsel. 2021. Fertility and milk production on commercial dairy farms with customized lactation lengths. J. Dairy Sci. 104:443-458. https://doi.org/10.3168/jds.2019-17947.

Butler, W. R., R. W. Everett, and C. E. Coppock. 1981. The relationships between energy balance, milk production and ovulation in postpartum Holstein cows. J. Anim. Sci. 53:742-748. https://doi .org/10.2527/jas1981.533742x.

Chen, J., A. Kok, G. J. Remmelink, J. J. Gross, R. M. Bruckmaier, B. Kemp, and A. T. M. Van Knegsel. 2016. Effects of dry period length and dietary energy source on lactation curve characteristics over 2 subsequent lactations. J. Dairy Sci. 99:9287-9299. https:// doi.org/10.3168/jds.2016-11253.

CVB. 2012. Cvb tabellenboek veevoeding [Feedstuff table 2012]. Centraal Veevoeder Bureau Lelystad.

Dekkers, J. C. M., J. H. Ten Hag, and A. Weersink. 1998. Economic aspects of persistency of lactation in dairy cattle. Livest. Prod. Sci. 53:237-252. https://doi.org/10.1016/S0301-6226(97)00124-3.

Ferguson, J. D., D. T. Galligan, and N. Thomsen. 1994. Principal descriptors of body condition in Holstein cows. J. Dairy Sci. 77:26952703. https://doi.org/10.3168/jds.S0022-0302(94)77212-X.

Friggens, N. C., J. B. Andersen, T. Larsen, O. Aaes, and R. J. Dewhurst. 2004. Priming the dairy cow for lactation: A review of dry cow feeding strategies. Anim. Res. 53:453-473. https://doi.org/10 .1051/animres:2004037.

Friggens, N. C., G. C. Emmans, and R. F. Veerkamp. 1999. On the use of simple ratios between lactation curve coefficients to describe parity effects on milk production. Livest. Prod. Sci. 62:1-13. https: //doi.org/10.1016/S0301-6226(99)00110-4.

Inchaisri, C., R. Jorritsma, P. L. A. M. Vos, G. C. van der Weijden, and H. Hogeveen. 2010. Economic consequences of reproductive performance in dairy cattle. Theriogenology 74:835-846. https:// doi.org/10.1016/j.theriogenology.2010.04.008.

ISO. 2013. 9622: Milk and liquid milk products. Guidelines for the application of mid-infrared spectrometry. 2:14. International Organization of Standardization.

Kok, A., J. O. Lehmann, B. Kemp, H. Hogeveen, C. E. van Middelaar, I. J. M. de Boer, and A. T. M. van Knegsel. 2019. Production, partial cash flows and greenhouse gas emissions of simulated dairy herds with extended lactations. Animal 13:1074-1083. https://doi .org/10.1017/S1751731118002562.

Kok, A., C. E. van Middelaar, B. Engel, A. T. M. van Knegsel, H. Hogeveen, B. Kemp, and I. J. M. de Boer. 2016. Effective lactation yield: A measure to compare milk yield between cows with different dry period lengths. J. Dairy Sci. 99:2956-2966. https:// doi.org/10.3168/jds.2015-10559.

Lee, J. Y., and I. H. Kim. 2006. Advancing parity is associated with high milk production at the cost of body condition and increased periparturient disorders in dairy herds. J. Vet. Sci. 7:161-166. https://doi.org/10.4142/jvs.2006.7.2.161.

Lehmann, J. O., J. G. Fadel, L. Mogensen, T. Kristensen, C. Gaillard, and E. Kebreab. 2016. Effect of calving interval and parity on milk yield per feeding day in danish commercial dairy herds. J. Dairy Sci. 99:621-633. https://doi.org/10.3168/jds.2015-9583.

Mellado, M., J. M. Flores, A. De Santiago, F. G. Veliz, U. MacíasCruz, L. Avendaño-Reyes, and J. E. García. 2016. Extended lactation in high-yielding Holstein cows: Characterization of milk yield and risk factors for lactations $>450$ days. Livest. Sci. 189:50-55. https://doi.org/10.1016/j.livsci.2016.05.004.

Niozas, G., G. Tsousis, C. Malesios, I. Steinhöfel, C. Boscos, H. Bollwein, and M. Kaske. 2019. Extended lactation in high-yielding dairy cows II. Effects on milk production, udder health, and body measurements. J. Dairy Sci. 102:811-823. https://doi.org/10 $.3168 /$ jds.2018-15117. 
Odensten, M. O., B. Berglund, K. P. Waller, and K. Holtenius. 2007. Metabolism and udder health at dry-off in cows of different breeds and production levels. J. Dairy Sci. 90:1417-1428. https://doi.org/ 10.3168/jds.S0022-0302(07)71627-2.

Österman, S., and J. Bertilsson. 2003. Extended calving interval in combination with milking two or three times per day: Effects on milk production and milk composition. Livest. Prod. Sci. 82:139149. https://doi.org/10.1016/S0301-6226(03)00036-8.

Poppe, M., R. F. Veerkamp, M. L. Van Pelt, and H. A. Mulder. 2020 Exploration of variance, autocorrelation, and skewness of deviations from lactation curves as resilience indicators for breeding. J. Dairy Sci. 103:1667-1684. https://doi.org/10.3168/jds.2019-17290.

Rajala-Schultz, P. J., J. S. Hogan, and K. L. Smith. 2005. Short communication: Association between milk yield at dry-off and probability of intramammary infections at calving. J. Dairy Sci. 88:577-579. https://doi.org/10.3168/jds.S0022-0302(05)72720-X.

Rehn, H., B. Berglund, U. Emanuelson, G. Tengroth, and J. Philipsson. 2000. Milk production in Swedish dairy cows managed for calving intervals of 12 and 15 months. Acta Agric. Scan. Anim. Sci. 50:263-271. https://doi.org/10.1080/090647000750069458.

Roche, J. R., and D. P. Berry. 2006. Periparturient climatic, animal, and management factors influencing the incidence of milk fever in grazing systems. J. Dairy Sci. 89:2775-2783. https://doi.org/10 .3168 /jds.S0022-0302(06)72354-2.

Silvestre, A. M., A. M. Martins, V. A. Santos, M. M. Ginja, and J. A. Colaço. 2009. Lactation curves for milk, fat and protein in dairy cows: A full approach. Livest. Sci. 122:308-313. https://doi.org/10 .1016/j.livsci.2008.09.017.

Steeneveld, W., and H. Hogeveen. 2012. Economic consequences of immediate or delayed insemination of a cow in oestrus. Vet. Rec. 171:17. https://doi.org/10.1136/vr.100183.

Strandberg, E., and C. Lundberg. 1991. A note on the estimation of environmental effects on lactation curves. Anim. Prod. 53:399-402. https://doi.org/10.1017/S0003356100020420.

Strandberg, E., and P. A. Oltenacu. 1989. Economic consequences of different calving intervals. Acta Agric. Scand. 39:407-420. https:/ /doi.org/10.1080/00015128909438534.

Zobel, G., D. M. Weary, K. E. Leslie, and M. A. G. von Keyserlingk. 2015. Invited review: Cessation of lactation: Effects on animal welfare. J. Dairy Sci. 98:8263-8277. https://doi.org/10.3168/jds.2015 -9617 .

\section{ORCIDS}

E. E. A. Burgers (ํ) https://orcid.org/0000-0002-1586-1570

A. Kok ๑ https://orcid.org/0000-0002-6024-5339

R. M. A. Goselink @ https://orcid.org/0000-0002-1610-0546

H. Hogeveen (1) https://orcid.org/0000-0002-9443-1412

B. Kemp 나 https://orcid.org/0000-0002-9765-9105

A. T. M. van Knegsel ( https://orcid.org/0000-0003-1959-3363

\section{APPENDIX}

Table A1. Mean range within blocks of the variables used to select cows for blocks: calving date (d), expected (primiparous cows) or previous (multiparous cows) 305-d milk yield ( $\mathrm{kg})$, parity, and breeding value for persistency

\begin{tabular}{lc}
\hline Variable & Mean range \\
\hline Calving date & 26 \\
305-d milk yield & 975 \\
Parity & 0.6 \\
Breeding value persistency & 4.9 \\
\hline
\end{tabular}

Table A2. Milk and fat- and protein-corrected milk yield (FPCM) per day of calving interval (CInt) ${ }^{1}$ and lactation persistency ${ }^{2}$ of primiparous and multiparous cows with CInt of $<415 \mathrm{~d}$ (CInt- 1$)$, 415 to $485 \mathrm{~d}$ (CInt-2), or $>485 \mathrm{~d}$ (CInt-3)

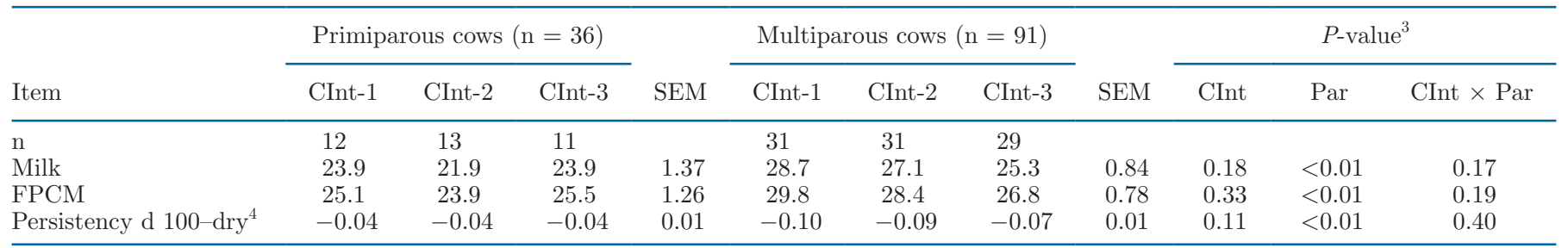

${ }^{1}$ Milk yield in the first lactation within the experiment per day of calving interval (kg of milk or kg of FPCM per day).

${ }^{2}$ Reduction in milk yield in the first lactation within the experiment ( $\mathrm{kg}$ of milk/d).

${ }^{3} \mathrm{Par}=$ parity class (primiparous or multiparous).

${ }^{4}$ Persistency between d 100 of lactation and dry-off. 